\title{
KATEGORI BADAN ATAU PEJABAT TATA USAHA NEGARA
}

\author{
MUHAMMAD AL DINO FAZMI \\ aldino1608@gmail.com \\ 2010003600079 \\ KELAS : $3 \mathrm{H} 4$ \\ FAKULTAS HUKUM \\ UNIVERSITAS EKA SAKTI PADANG
}

\section{A. PENDAHULUAN}

Indonesia adalah negara hukum. Hal ini tertuang dalam Pasal 1 ayat 3 UndangUndang Dasar Negara Republik Indonesia 1945 yang berbunyi “Negara Indonesia adalah negara hukum", hal ini dapat diketahui dari salah satu syarat negara hukum bahwa Indonesia memiliki badan peradilan Tata Usaha Negara. Hal ini berarti adanya interaksi antara badan atau pejabat Tata Usaha Negara dalam upaya kritik dan penolakan terhadap putusan badan atau pejabat Tata Usaha Negara itu sendiri dalam menjalankan fungsinya. Di dalam suatu negara hukum terjadinya kritik dan penolakan tersebut terjadi keren adanya putusan yang dianggap tidak sesuai dan seringkali melanggar hak konstitusional seseorang. Negara memberikan fasilitas kepada warga negara yang merasa dirugikan dan ingin mencari keadilan atas tindakan yang tidak sesuai yang dilakukan oleh Pejabat Administrasi Negara melalui Peradilan Tata Usaha Negara.

Dasar hukum pembentukan Tata Usaha Negara yakni Undang-Undang Nomor: 5 Tahun 1986, tentang Peradilan Tata Usaha Negara dan Peraturan Pemerintah Nomor 41 Tahun 1991 tentang Pembentukan Pengadilan Tata Usaha Negara. Tempat Kedudukan 
Pengadilan (Pasal 6 Undang-Undang Nomor 9 Tahun 2004) Pengadilan Tata Usaha Negara (PTUN) berkedudukan di ibukota Kabupaten/Kota, dan daerahnya meliputi wilayah Kabupaten/Kota. Pengadilan Tinggi Tata Usaha Negara (PT. TUN) berkedudukan di ibukota Propinsi, dan daerah hukumnya meliputi Propinsi.

Peradilan Tata Usaha Negara merupakan lingkungan peradilan di bawah Mahkamah Agung sebagai pelaku kekuasaan kehakiman yang merdeka, untuk menyelenggarakan peradilan guna menegakkan hukum dan keadilan. Peradilan Tata Usaha Negara adalah salah satu pelaku kekuasaan kehakiman bagi rakyat pencari keadilan terhadap sengketa Tata Usaha Negara. Pengadilan Tata Usaha Negara adalah pengadilan tingkat pertama yang berkedudukan di ibukota Kabupaten/Kota, dan daerah hukumnya.adalah meliputi kabupaten/kota. Sementara Pengadilan Tinggi Tata Usaha Negara adalah peradilan tingkat banding yangberkedudukan di ibukota Provinsi, dan daerah hukumnya meliputi wilayah Provinsi.

Tujuan mempelajari Peradilan Tata Usaha Negara (PTUN) yakni untuk memahami tentang hukum administrasi negara yang membahas tentang hal-hal dasar mengenai bagaimana seseorang beracara di Peradilan Tata Usaha Negara, subjek, objek, kompetensi Peradilan Tata Usaha Negara, alur penyelesaian sengketa, gugatan, schorsing, pembuktian, upaya hukum dan bagaimana cara menjalankan eksekusi di Peradilan Tata Usaha Negara.

\section{B. KATEGORI BADAN ATAU PEJABAT TATA USAHA NEGARA}

Secara normatif sebagaimana dinyatakan dalam Pasal 1 angka 8 UU Peradilan TUN, maka Badan/Pejabat TUN adalah Badan atau Pejabat yang melaksanakan urusan 
pemerintahan berdasarkan peraturan perundang-undangan yang berlaku. Adapun mengenai Badan atau Pejabat TUN itu sendiri kadang masih menimbulkan kebingungan akibat pengertiannya dalam UU PTUN. Berdasarkan pengertian di atas dapat dilihat bahwa pengertian Badan atau Pejabat TUN sangatlah luas. Ini berarti Badan atau Pejabat apa saja yang melakukan urusan pemerintahan (eksekutif) bisa dikatakan sebagai Badan atau Pejabat TUN. Mengenai hal ini, Badan Litbang Diklat Hukum dan Peradilan Mahkamah Agung RI pernah melakukan kajian terkait makna Pejabat TUN dan mencapai beberapa poin kesimpulan:

1. Secara normatif Badan atau Pejabat TUN adalah Badan atau Pejabat yang melaksanakan urusan pemerintahan berdasarkan peraturan perundang-undangan yang berlaku;

2. Tolok ukur penentuan Badan atau Pejabat TUN adalah pada fungsi yang dilaksanakan, dan bukan dari nama jabatan atau kedudukan strukturalnya; dan

3. Pejabat TUN harus dimaknai sebagai siapa pun yang melaksanakan fungsi pemerintahan, sehingga harus tunduk pada peraturan perundang-undangan yang berlaku.

W. Riawan Tjandra dalam bukunya Hukum Acara Peradilan Tata Usaha Negara menyatakan bahwa penentuan pejabat yang melaksanakan urusan pemerintahan dikategorikan secara fungsional, sehingga tidak terbatas pada pejabat resmi negara saja, namun juga bisa pihak lain yang berdasarkan peraturan perundang-undangan diberi tugas untuk melaksanakan suatu tugas/ fungsi urusan pemerintahan. Tidak hanya itu, selain berdasarkan wewenang yang ada padanya, dapat juga karena adanya wewenang yang dilimpahkan kepadanya.

Adapun objek yang dapat digugat kepada Pengadilan TUN ("PTUN") merupakan Keputusan Tata Usaha Negara (Beschiking) yang merupakan penetapan tertulis yang 
dikeluarkan oleh badan atau pejabat tata usaha negara yang berisi tindakan hukum tata usaha negara yang berdasarkan peraturan perundang-undangan yang berlaku, yang bersifat konkret, individual, dan final, yang menimbulkan akibat hukum bagi seseorang atau badan hukum perdata.

Berdasarkan penjelasan di atas, maka banyak Badan atau Pejabat TUN yang sekilas dalam namanya tidak mengandung unsur-unsur istilah yang mengindikasikannya sebagai Badan atau Pejabat yang melaksanakan urusan pemerintahan, namun jika ditelaah fungsinya sebenarnya adalah Badan atau Pejabat TUN dan keputusan-keputusannya dapat menimbulkan sengketa yang diperiksa di PTUN. Kebanyakan orang memahami Badan atau Pejabat TUN seperti Direktur Jenderal pada Kementerian dan Kepala Kantor Pertanahan. Namun ada pula badan-badan lain seperti Badan Usaha Milik Negara (BUMN) karena pendirinya yang merupakan Menteri.

Adapun Badan atau Pejabat yang termasuk kategori Badan atau Pejabat TUN sebagaimana dijabarkan oleh H. Ujang Abdullah, SH., MSi, di antaranya:

1. Badan atau Pejabat instansi resmi Pemerintah seperti Pemerintah Pusat, Pemerintah Daerah, Pemerintah Kabupaten/Kota, dan instansi resmi Pemerintah yang berada di lingkungan eksekutif;

2. Badan atau Pejabat semi Pemerintah seperti BUMN, BUMD, dan lain-lain termasuk yang juga merupakan kerja sama Pemerintah dengan swasta; dan

3. Badan atau Pejabat swasta yang melaksanakan urusan pemerintahan seperti yayasan yang bergerak di bidang yang seharusnya menjadi kewajiban Pemerintah tetapi dilaksanakan oleh swasta, seperti Perguruan Tinggi, Rumah Sakit, dll. 
Untuk lebih spesifiknya lagi, dalam Undang-Undang Nomor 12 Tahun 2012 tentang Pendidikan Tinggi (“UU Pendidikan Tinggi”), Perguruan Tinggi merupakan satuan pendidikan penyelenggara pendidikan tinggi. Sedangkan dalam Peraturan Pemerintah Nomor 4 Tahun 2014 tentang Penyelenggaraan Pendidikan Tinggi dan Pengelolaan Perguruan Tinggi ("PP 4/2014"), pemimpin Perguruan Tinggi adalah rektor. Rektor menjalankan fungsi penetapan kebijakan non akademik dan pengelolaan Perguruan Tinggi untuk dan atas nama menteri.

Sebelumnya perlu juga dipahami definisi dari Universitas dalam Pasal 1 angka 7 PP 4/2014 berikut:

Universitas adalah Perguruan Tinggi yang menyelenggarakan pendidikan akademik dan dapat menyelenggarakan pendidikan vokasi dalam berbagai rumpun ilmu pengetahuan dan/atau teknologi dan jika memenuhi syarat, Universitas dapat menyelenggarakan pendidikan profesi.

Adapun senat Universitas pada Perguruan Tinggi Nasional ("PTN") merupakan unsur penyusun kebijakan yang menjalankan fungsi penetapan kebijakan akademik dan pemberian pertimbangan pelaksanaan kebijakan akademik. Sementara senat Universitas pada PTN Badan Hukum, menjalankan fungsi penetapan kebijakan, pemberian pertimbangan, dan pengawasan di bidang akademik.

Dalam bukunya, Usaha Memahami Undang-Undang tentang Peradilan Tata Usaha Negara (1993), Indroharto menegaskan bahwa siapa saja dan apa saja yang berdasarkan peraturan perundang-undangan yang berlaku berwenang melaksanakan suatu bidang urusan pemerintahan, maka ia dapat dianggap berkedudukan sebagai Badan atau Pejabat TUN. Dengan dasar tersebut, senat dapat saja dikategorikan sebagai Pejabat TUN mengingat fungsi dan kewenangannya masih terkait dengan penyelenggaraan Pendidikan Tinggi dalam Perguruan Tinggi, meskipun tidak dapat dipersamakan dengan kedudukan Rektor yang memiliki 
kewenangan atributif. Hanya saja terdapat perbedaan mendasar sifat kebijakan yang dikeluarkan senat yang bersifat akademik dengan rektor yang bersifat non akademik. Dalam Peraturan Menteri Pendidikan dan Kebudayaan Nomor 139 Tahun 2014 tentang Pedoman Statuta dan Organisasi Perguruan Tinggi (“Permendikbud 139/2014"), senat mengeluarkan penetapan kebijakan, norma/etika dan kode etik akademik di samping melakukan pengawasan dan pemberian rekomendasi kebijakan kepada rektor.

Mengacu pada kewenangan tersebut, kebijakan akademik yang dikeluarkan senat lebih bersifat abstrak-umum (Beleidsregel) dan tidak individual-konkret (Beschikking) yang dapat menjadi objek gugatan Tata Usaha Negara. Di samping itu, kewenangan lain yang dimiliki senat terbatas pada pemberian rekomendasi yang tidak dapat menimbulkan akibat hukum sebelum adanya keputusan pejabat lain yang memiliki kewenangan dalam peraturan perundang-undangan. Dari situ, dapat kita lihat bahwa produk hukum yang dikeluarkan senat berdasarkan peraturan tidak termasuk objek TUN.

Terhadap permasalahan ini, terdapat Putusan PTUN Makassar Nomor 10/G/2014/PTUN.Mks. yang memutuskan tidak dapat menerima (niet onvangkelijke verklaard) gugatan terhadap senat dengan alasan produk hukum yang dikeluarkan senat bukan merupakan Keputusan (Beschikking) meskipun Majelis hakim tidak membantah dalil bahwa Senat merupakan Pejabat TUN. Dalam Putusan PTUN Palembang Nomor 13/G/2016/PTUN-PLG, majelis hakim menyatakan senat merupakan Pejabat TUN karena melakukan kegiatan bersifat eksekutif, meski kemudian menolak gugatan juga karena sifatnya yang bukan Beschikking.

Dengan kata lain, senat dapat saja dikategorikan sebagai Pejabat TUN mengingat fungsi dan kewenangannya masih terkait dengan penyelenggaraan Pendidikan Tinggi dalam Perguruan 
Tinggi (eksekutif), meskipun tidak dapat dipersamakan dengan kedudukan rektor yang memiliki kewenangan atributif. Hanya saja, dalam peraturan perundang-undangan, produk hukum yang dapat dikeluarkan senat bukan termasuk objek TUN karena lebih bersifat abstrak-umum (Beleidsregel) daripada individual-konkret (Beschikking) dan lainnya masih bersifat rekomendasi yang belum memiliki akibat hukum sebelum diputuskan pejabat lain yang berwenang. Untuk menentukan posibilitas gugatan TUN, Anda tidak dapat mendasarkannya hanya pada penentuan kedudukan sebagai Pejabat TUN saja, melainkan pada sifat dari produk hukum tersebut apakah bersifat konkret, individual, dan final, yang menimbulkan akibat hukum bagi seseorang atau badan hukum perdata. Penentuan ukuran tersebut dapat berbeda di masingmasing kasusnya.

\section{KESIMPULAN}

Secara normatif sebagaimana dinyatakan dalam Pasal 1 angka 8 UU Peradilan TUN, maka Badan/Pejabat TUN adalah Badan atau Pejabat yang melaksanakan urusan pemerintahan berdasarkan peraturan perundang-undangan yang berlaku. Adapun objek yang dapat digugat kepada Pengadilan TUN ("PTUN") merupakan Keputusan Tata Usaha Negara (Beschiking) yang merupakan penetapan tertulis yang dikeluarkan oleh badan atau pejabat tata usaha negara yang berisi tindakan hukum tata usaha negara yang berdasarkan peraturan perundang-undangan yang berlaku, yang bersifat konkret, individual, dan final, yang menimbulkan akibat hukum bagi seseorang atau badan hukum perdata.

Dengan kata lain, senat dapat saja dikategorikan sebagai Pejabat TUN mengingat fungsi dan kewenangannya masih terkait dengan penyelenggaraan Pendidikan Tinggi dalam Perguruan Tinggi (eksekutif), meskipun tidak dapat dipersamakan dengan kedudukan rektor yang memiliki kewenangan atributif. Hanya saja, dalam peraturan perundang-undangan, produk hukum yang 
dapat dikeluarkan senat bukan termasuk objek TUN karena lebih bersifat abstrak-umum (Beleidsregel) daripada individual-konkret (Beschikking) dan lainnya masih bersifat rekomendasi yang belum memiliki akibat hukum sebelum diputuskan pejabat lain yang berwenang. 


\section{DAFTAR PUSTAKA}

Darmini Roza dan Laurensius Arliman S, Peran Pemerintah Daerah Di Dalam Melindungi Hak Anak Di Indonesia, Masalah-Masalah Hukum, Volume 47, Nomor 1, 2018. https://doi.org/10.14710/mmh.47.1.2018.10-21

Laurensius Arliman S, Peranan Metodologi Penelitian Hukum di Dalam Perkembangan Ilmu Hukum di Indonesia, Soumatera Law Review, Volume 1, Nomor 1, 201. http://doi.org/10.22216/soumlaw.v1i1.3346.

Laurensius Arliman S, Peran Badan Permusyawaratan Desa di Dalam Pembangunan Desa dan Pengawasan Keuangan Desa, Padjadjaran Journal of Law, Volume 4, Nomor 3, 2017. https://doi.org/10.15408/jch.v4i2.3433.

Laurensius Arliman S, Penanaman Modal Asing Di Sumatera Barat Berdasarkan Undang- Undang Nomor 25 Tahun 2007 Tentang Penanaman Modal, Supremasi Hukum, Volume 1, Nomor 1, 2018. http://dx.doi.org/10.36441/hukum.v1i01.102 .

Laurensius Arliman S, Memperkuat Kearifan Lokal Untuk Menangkal Intoleransi Umat Beragama Di Indonesia, Ensiklopedia of Journal, Volume 1, Nomor 1, 2018, https://doi.org/10.33559/eoj.v1i1.18.

Laurensius Arliman S, Perkawinan Antar Negara Di Indonesia Berdasarkan Hukum Perdata Internasional, Kertha Patrika, Volume 39, Nomor 3, 2017, https://doi.org/10.24843/KP.2017.v39.i03.p03.

Laurensius Arliman S, Partisipasi Masyarakat Di Dalam Pengelolaan Uang Desa PascaUndang-Undang Nomor 6 Tahun 2014 Tentang Desa, Jurnal Arena Hukum, Volume 12, Nomor 2, 2019, https://doi.org/10.21776/ub.arenahukum.2019.01202.5.

Laurensius Arliman S, Mewujudkan Penegakan Hukum Yang Baik Di Negara Hukum Indonesia, Dialogica Jurnalica, Volume 11, Nomor 1, 2019, https://doi.org/10.28932/di.v11i1.1831.

Laurensius Arliman S, Mediasi Melalui Pendekatan Mufakat Sebagai Lembaga Alternatif Penyelesaian Sengketa Untuk Mendukung Pembangunan Ekonomi Nasional, UIR Law Review, Volume 2, Nomor 2, 2018, https://doi.org/10.25299/uirlrev.2018.vol2(02).1587

Laurensius Arliman S, Peranan Filsafat Hukum Dalam Perlindungan Hak Anak Yang Berkelanjutan Sebagai Bagian Dari Hak Asasi Manusia, Doctrinal, Volume 1, Nomor 2,2016.

Laurensius Arliman S, Ni Putu Eka Dewi, Protection of Children and Women's Rights in Indonesia through International Regulation Ratification, Journal of Innovation, Creativity and Change Volume 15, Nomor 6, 2021. 
Laurensius Arliman S, Gagalnya Perlindungan Anak Sebagai Salah Satu Bagian Dari Hak Asasi Manusia Oleh Orang Tua Ditinjau Dari Mazhab Utilitarianisme, Jurnal Yuridis, Volume 3, Nomor 2, 2016, http://dx.doi.org/10.35586/.v3i2.180.

Laurensius Arliman S, Tantangan Pendidikan Kewarganegaraan Pada Revolusi 4.0, Jurnal Ensiklopedia Sosial Review, Volume 2, Nomor 3, 2020.. 